\title{
Purification and characterization of a thermostable, haloalkaliphilic extracellular serine protease from the extreme halophilic archaeon Halogeometricum borinquense strain TSS101
}

\author{
MALASHETTY VIDYASAGAR,${ }^{1} \mathrm{~S}$. PRAKASH,${ }^{1}$ CAROL LITCHFIELD ${ }^{2}$ and \\ K. SREERAMULU ${ }^{1,3}$ \\ ${ }^{1}$ Department of Biochemistry, Gulbarga University, Gulbarga-585 106, Karnataka, India \\ ${ }^{2}$ Department of Environmental Science \& Policy, George Mason University, 10900 University Blvd., PW1 MS 4D4, Manassas, Virginia, 20110 \\ ${ }^{3}$ Corresponding author (ksramu@rediffmail.com)
}

Received April 6, 2006; accepted May 23, 2006; published online June 19, 2006

\begin{abstract}
Summary A novel haloalkaliphilic, thermostable serine protease was purified from the extreme halophilic archaeon, Halogeometricum borinquense strain TSS101. The protease was isolated from a stationary phase culture, purified 116-fold with $18 \%$ yield and characterized biochemically. The molecular mass of the purified enzyme was estimated to be $86 \mathrm{kDa}$. The enzyme showed the highest activity at $60{ }^{\circ} \mathrm{C}$ and $\mathrm{pH} 10.0$ in $20 \% \mathrm{NaCl}$. The enzyme had high activity over the $\mathrm{pH}$ range from 6.0 to 10.0. Enzymatic activity was strongly inhibited by $1 \mathrm{mM}$ phenyl methylsulfonyl fluoride, but activity was increased $59 \%$ by $0.1 \%$ cetyltrimethylammonium bromide. The enzyme exhibited relatively high thermal stability, retaining $80 \%$ of its activity after $1 \mathrm{~h}$ at $90{ }^{\circ} \mathrm{C}$. Thermostability increased in the presence of $\mathrm{Ca}^{2+}$. The stability of the enzyme was maintained in $10 \%$ sucrose and in the absence of $\mathrm{NaCl}$.
\end{abstract}

Keywords: calcium chloride, cetyltrimethylammonium bromide, halophilic serine protease, metal ions, osmolytes, protease inhibitors.

\section{Introduction}

The haloarchaea are aerobic, extreme halophiles that grow optimally in medium containing $15-25 \% \mathrm{NaCl}$ (Kushner and Kamekura 1988), although most species can grow over a wide range of salinities. Many extreme and moderate halophiles have been isolated and investigated for possible biotechnological applications, including the production of compatible solutes, enhanced oil recovery and the degradation of industrial pollutants in saline habitats (Hough and Danson 1999, Madern et al. 2000, Margesin and Schiner 2001, Schiraldi et al. 2002, Van den Berg 2003, Gomes and Steiner 2004). Additionally, halophiles produce exoenzymes of potential commercial value (Thongthai and Sontinanalert 1991, Adams and Kelly 1995). Some extracellular proteases from halophiles have maximal activity at near neutral pH (Norberg and Hofstein 1969, Izotova et al. 1983, Kamekura and Seno 1990, Schmitt et al. 1990,
Stepanov et al. 1992). A few extracellular proteases from haloalkaliphilic archaea have been characterized (Studdert et al. 1997, Gimenez et al. 2000), and their activity has been found to depend on both a high salt concentration and a high $\mathrm{pH}$. Here, we report on the purification and characterization of a haloalkaliphilic extracellular protease from the extreme halophilic archaeon Halogeometricum borinquense strain TSS101.

\section{Materials and methods}

\section{Organism}

We isolated $H$. borinquense strain TSS101 from solar salterns of Tuticorin, Tamilnadu, India. The organism strain was identified based on 16S rRNA sequencing, membrane lipid analysis and physiological properties. Halogeometricum borinquense is a gram negative, extremely pleomorphic and rodshaped organism forming pink pigmented colonies. Strictly aerobic, $H$. borinquense grows at $\mathrm{pH}$ 6.0-10.0, temperatures of $25-45{ }^{\circ} \mathrm{C}$ and $\mathrm{NaCl}$ concentrations of $15-25 \%$. Optimal growth occurs at $\mathrm{pH} 7.0-7.5,40{ }^{\circ} \mathrm{C}$ and $20 \% \mathrm{NaCl}$. Halogeometricum borinquense lipids include glycerol diether moieties, indicative of an extreme halophilic archaeon. A high salt requirement, resistance to kanamycin, penicillin and chloramphenicol (which inhibit growth of halophilic eubacteria) and susceptibility to bacitracin, place this microorganism in the family Halobacteriaceae, order Halobacteriales (MontalvoRodriguez et al. 1998). The H. borinquense strain TSS101 has been deposited at the National Centre for Industrial Microorganisms, Pune, India (Accession No. NCIM 5238). The $16 \mathrm{~S}$ rRNA sequence has been deposited in the NCBI database (Accession No. DQ375808).

\section{Growth conditions and media composition}

The archaeon $H$. borinquinse strain TSS101 was cultured aerobically at $40^{\circ} \mathrm{C}$ in a $250-\mathrm{ml}$ flask containing $50 \mathrm{ml}$ of growth 


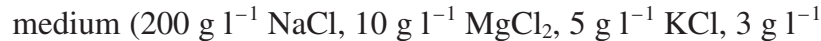
trisodium citrate and $10 \mathrm{~g} \mathrm{l}^{-1}$ peptone; $\mathrm{pH}$ 7.2) and shaken at $200 \mathrm{rpm}$.

\section{Enzyme purification}

Purification was carried out at room temperature $\left(25^{\circ} \mathrm{C}\right)$. The microorganism was grown at $40{ }^{\circ} \mathrm{C}$ for 4 days, centrifuged at $10,000 \mathrm{~g}$ for $10 \mathrm{~min}$ and the supernatant retained as the source of extracellular enzyme. One liter of crude enzyme was concentrated to $20 \mathrm{ml}$ with a membrane protein concentrator (MWC $50 \mathrm{kDa}$ Nalgene). The concentrated enzyme was precipitated by the drop-wise addition of $10 \mathrm{ml}$ of chilled absolute ethanol with constant stirring. After $2 \mathrm{~h}$ at $-10{ }^{\circ} \mathrm{C}$, the precipitate was recovered by centrifugation at $16,000 \mathrm{~g}$ for $20 \mathrm{~min}$. The precipitate was resuspended in $5 \mathrm{ml}$ of $50 \mathrm{mM}$ glycine$\mathrm{NaOH}$ buffer ( $\mathrm{pH} 10.0$ ) containing $20 \% \mathrm{NaCl}$ and dialyzed in the same buffer. The dialyzed sample was passed through a sephacryl S-200 gel permeation column $(1.6 \times 60 \mathrm{~cm})$ equilibrated with $50 \mathrm{mM}$ glycine- $\mathrm{NaOH}$ buffer ( $\mathrm{pH}$ 10.0) containing $20 \% \mathrm{NaCl}$. The flow rate was $0.2 \mathrm{ml} \mathrm{min}^{-1}$ and $2 \mathrm{ml}$ fractions were collected and analyzed for protein content and azocaseinase activity. The active fractions were pooled, concentrated and passed through a G-75 column $(2 \times 30 \mathrm{~cm})$ equilibrated with $50 \mathrm{mM}$ glycine- $\mathrm{NaOH}$ buffer ( $\mathrm{pH}$ 10.0) containing $20 \% \mathrm{NaCl}$ and re-analyzed. Aliquots of the purified enzyme were inactivated with $5 \mathrm{mM}$ of the serine protease inhibitor, phenylmethylsulphonylfluoride (PMSF) $\left(1 \mathrm{~h}, 25^{\circ} \mathrm{C}\right)$, and exhaustively dialyzed against water containing $1 \mathrm{mM}$ PMSF to remove salts. The dialyzed sample was examined by sodium dodecyl sulphate $(8 \%)$ polyacrylamide gel electrophoresis (SDS-PAGE, Laemmli 1970). Total protein was determined by the method of Lowry et al. (1951), with crystalline bovine serum albumin (BSE, Sigma Chemical) as the standard.

\section{Azocaseinase assay}

Azocaseinase activity was determined by a modification of the method of Brock et al. (1982). One $\mathrm{ml}$ of $0.4 \%$ azocasein (Sigma-Aldrich) was dissolved in $0.1 \mathrm{M}$ glycine- $\mathrm{NaOH}$ buffer (pH 10.0) containing $20 \% \mathrm{NaCl}$ in Eppendorf tubes $(1.5 \mathrm{ml}$ ) and pre-incubated at $60{ }^{\circ} \mathrm{C}$. The reaction was initiated by the addition of 50-100 $\mu 1$ of enzyme solution. After incubation at $60{ }^{\circ} \mathrm{C}$ for $15 \mathrm{~min}$, the reaction was terminated by the addition of $500 \mu \mathrm{l}$ of $20 \%$ (w/v) trichloroacetic acid (TCA). The tubes were incubated at room temperature for $30 \mathrm{~min}$, and then centrifuged at $10,000 \mathrm{~g}$ for $5 \mathrm{~min}$. The absorbance of the supernatant at $450 \mathrm{~nm}$ was determined. One unit (U) of azocaseinase activity was defined as the amount of enzyme that produced an absorbance change at $450 \mathrm{~nm}$ of $0.01 \mathrm{~min}^{-1}$ under standard assay conditions. All assays were performed in triplicate.

\section{Substrate specificity}

Protease activity was determined by measuring the amount of $p$-nitroaniline released from the substrate benzoyl-DL-arginine $p$-nitroanilide (BAPNA) prepared in glycine/ $\mathrm{NaOH}$ buffer (pH 10.0) containing $20 \% \mathrm{NaCl}$. The esterolytic activity was determined with benzoyl-L-arginine ethyl ester (BAEE), $p$-tosyl-L-arginine methyl ester (TAME) and benzoyl-L-tyrosine ethyl ester (BTEE) (Sigma) as described by Strongin et al. (1978) with slight modification. Briefly, the reaction mixture consisted of $0.1 \mathrm{ml}$ of enzyme solution in $100 \mathrm{mM}$ glycine$\mathrm{NaOH}, \mathrm{pH} 10.0,20 \% \mathrm{NaCl}, 100 \mathrm{mM} \mathrm{CaCl}_{2}$ and $1 \mathrm{ml}$ of the substrate. Activity was monitored as the increase in absorbance at $254 \mathrm{~nm}$.

\section{Effect of $\mathrm{pH}$, temperature and $\mathrm{NaCl}$}

Protease activity of the purified enzyme was measured at $\mathrm{pH}$ $5.0-11.0$ at a temperature of $60{ }^{\circ} \mathrm{C}$ in $20 \% \mathrm{NaCl}(\mathrm{w} / \mathrm{v})$, with azocasein as a substrate. A plot of relative activity against $\mathrm{pH}$ was constructed to determine the optimum $\mathrm{pH}$ for the reaction. The effect of temperature on protease activity of the purified enzyme was measured at $30,40,50,60,70,80$ and $90^{\circ} \mathrm{C}$ at $\mathrm{pH}$ 10.0 in $20 \% \mathrm{NaCl}(\mathrm{w} / \mathrm{v})$, with azocasein as substrate. The protease activity of the purified enzyme was measured at $\mathrm{NaCl}$ concentrations of $0,5,10,15,20,25$ and $30 \%(w / v)$ at $60{ }^{\circ} \mathrm{C}$ and $\mathrm{pH} 10.0$.

\section{Thermal stability}

The purified enzyme was incubated at various temperatures from 30 to $95{ }^{\circ} \mathrm{C}$ for $1 \mathrm{~h}$ at $\mathrm{pH} 10.0$, and the azocaseinolytic activity subsequently assayed at $60{ }^{\circ} \mathrm{C}$ and $\mathrm{pH} 10.0$ in the presence of $20 \% \mathrm{NaCl}(\mathrm{w} / \mathrm{v})$.

\section{Effect of metal ions and inhibitors}

The effects of various metal ions, detergents and inhibitors were tested on the activity of purified enzyme at $60{ }^{\circ} \mathrm{C}$ in glycine- $\mathrm{NaOH}$ buffer ( $\mathrm{pH} 10.0$ ) containing $20 \% \mathrm{NaCl}$ (w/v), with azocasein as a substrate. The enzyme was preincubated with $1 \mathrm{mM}$ of metal ions, such as $\mathrm{K}, \mathrm{Ba}, \mathrm{Co}, \mathrm{Cu}, \mathrm{Mg}, \mathrm{Mn}, \mathrm{Hg}$, $\mathrm{Zn}$ and $\mathrm{Ca}(100 \mathrm{mM})$, for $10 \mathrm{~min}$ under standard conditions. Activity was measured as described above. The increase or decrease in enzyme activity was calculated relative to a control.

\section{Effect of osmolytes}

The activity of the purified enzyme in the absence of $\mathrm{NaCl}$ was measured in the presence of various concentrations (w/v) of the osmolytes betaine, sucrose, glycerol and mannitol in the absence of $\mathrm{NaCl}$, at $\mathrm{pH} 10.0$ and at $60^{\circ} \mathrm{C}$, with azocasein as substrate.

\section{Results}

Results of the purification of the protease secreted by H. borinquense strain TSS101 are summarized in Table 1. The active extracellular protease was isolated from the culture filtrate by alcohol precipitation and gel permeation chromatography. $\mathrm{Pu}-$ rification of halophilic protease was performed in the presence of $20 \% \mathrm{NaCl}$, so that the enzyme would maintain a high specific activity against azocasein. The protease was purified 116 -fold, with a final yield of $18 \%$. The specific activity of the purified enzyme was $350 \mathrm{U} \mathrm{m} \mathrm{g}^{-1}$ protein. Analysis of the purified enzyme by SDS-PAGE revealed a single band with a 
Table 1. Purification of a serine protease of Halogeometricum borinquense strain TSS101.

\begin{tabular}{|c|c|c|c|c|c|}
\hline Purification step & $\begin{array}{l}\text { Volume } \\
(\mathrm{ml})\end{array}$ & $\begin{array}{l}\text { Protein concentration } \\
\left(\mathrm{mg} \mathrm{ml}^{-1}\right)\end{array}$ & $\begin{array}{l}\text { Specific activity } \\
\text { (U mg }{ }^{-1} \text { protein) }\end{array}$ & $\begin{array}{l}\text { Purification } \\
\text { fold }\end{array}$ & $\begin{array}{l}\text { Yield } \\
(\%)\end{array}$ \\
\hline Culture medium supernatant & 1000 & 5.6 & 3 & 1 & 100 \\
\hline Protein concentrator Nalgene $(50 \mathrm{kD})$ & 20 & 15.6 & 30 & 10 & 55 \\
\hline Ethanol precipitate & 5 & 42 & 35 & 12 & 44 \\
\hline Gel permeation Sephacryl S-200 & 20 & 0.9 & 294 & 97 & 31 \\
\hline Gel permeation G-75 & 15 & 0.6 & 350 & 116 & 18 \\
\hline
\end{tabular}

molecular mass of $86 \mathrm{kDa}$ as determined by SDS-PAGE (Figure 1). The molecular mass of the active enzyme as estimated by GSK 2000 gel filtration column was $78 \mathrm{kDa}$.

The enzyme exhibited greatest activity in the $\mathrm{pH}$ range of 6.0-10.0, with an optimum $\mathrm{pH}$ of 10.0 (Figure 2). Activities at $\mathrm{pH} 5.0,11.0$ and 12.0 were 10,70 and $45 \%$, respectively, of the activity at $\mathrm{pH} 10.0$. The enzyme was stable over a broad $\mathrm{pH}$ range of $6.0-10.0$ at $60{ }^{\circ} \mathrm{C}$ (data not shown), indicating that it is an alkalophilic enzyme.

In the presence of calcium ions, the optimum temperature for enzyme activity was $60-70{ }^{\circ} \mathrm{C}$ (Figure 3 ). However, in the absence of calcium, there was a distinct optimum at $60{ }^{\circ} \mathrm{C}$ with

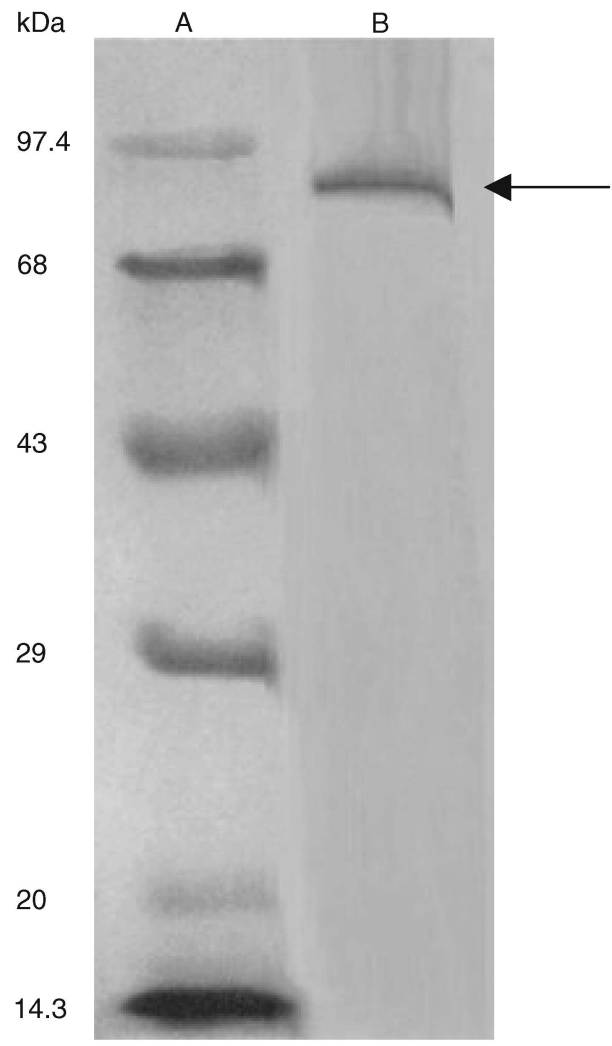

Figure 1. The sodium dodecyl sulfate polyacrylamide gel electrophoresis of the purified protease from Halogeometricum borinquense strain TSS101. Lane A shows relative molecular mass standards: phosphorylase b (97.4 kDa); bovine serum albumin-(68 kDa); ovalbumin $(43 \mathrm{kDa})$; carbonic anhydrase $(29 \mathrm{kDa})$; soyabean trypsin inhibitor $(20 \mathrm{kDa})$; and lysozyme $(14.3 \mathrm{kDa})$. Lane B shows the purified protease $(86 \mathrm{kDa}$, indicated by arrow). a $25 \%$ loss in activity at $70{ }^{\circ} \mathrm{C}$. Sixty percent of the optimal activity was retained in the $70-90{ }^{\circ} \mathrm{C}$ range. Less than $40 \%$ of the activity remained at $37{ }^{\circ} \mathrm{C}$ with or without calcium and $95^{\circ} \mathrm{C}$ in the absence of calcium. Thus, the enzyme was alkaliphilic and moderately thermostable (Figure 4).

The enzyme was stable at $60{ }^{\circ} \mathrm{C}$ for 2 hours and could be stored for 30 days at $4{ }^{\circ} \mathrm{C}$ without loss of activity in the presence of $20 \% \mathrm{NaCl}$. In absence of $\mathrm{NaCl}$, all activity was lost. Over the range of $0-30 \%(\mathrm{w} / \mathrm{v}) \mathrm{NaCl}$, maximal protease activity was observed in the presence of 20-25\% $\mathrm{NaCl}$ (Figure 5). At an $\mathrm{NaCl}$ concentration of $30 \%$, activity was $65 \%$ of the maximum.

Among the metal ions tested, only $\mathrm{Ca}^{2+}$ stimulated $(21 \%)$ the activity of the enzyme (Table 2; Figure 6). Protease activity was completely inhibited by $\mathrm{Cu}^{2+}$ and $\mathrm{Zn}^{2+}$. The thermostability of the enzyme was increased by $10{ }^{\circ} \mathrm{C}$ in presence of $\mathrm{Ca}^{2+}$. Other metal ions like $\mathrm{Co}^{2+}, \mathrm{Ba}^{2+}, \mathrm{Hg}^{2+}$ and $\mathrm{Mg}^{2+}$ had no significant effect on the activity of the enzyme. The enzyme was completely inhibited by $1 \mathrm{mM}$ PMSF, a serine protease inhibitor, but not by 1,10-phenanthroline (Table 3). Neither dithiothreitol (DTT) nor 2-mercaptoethanol affected enzyme activity. Inhibitors of sulfhydryl protease (PCMB, $\mathrm{HgCl}_{2}$ ), metalloprotease (EDTA) and aspartic protease (pepstatin) were also without effect on the activity of the enzyme. These results are consistent with the enzyme being a serine protease. The enzyme retained $53 \%$ of maximal activity at $0.1 \%$ SDS, but at $0.5 \%$ SDS, all activity was lost. Cetyltrimethylammonium bromide $(0.1 \%)$ enhanced activity by $59 \%$.

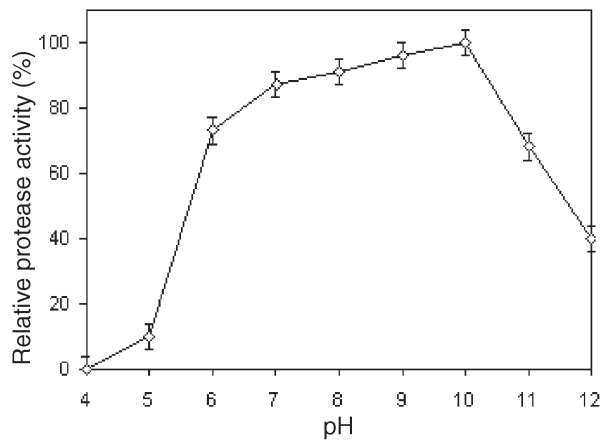

Figure 2. Activity of purified protease from Halogeometricum borinquense strain TSS101 at different $\mathrm{pH}$ values. Azocaseinolytic activity was measured at $60{ }^{\circ} \mathrm{C}$ in the presence of $20 \% \mathrm{NaCl}$ in the indicated buffers at a concentration of $0.1 \mathrm{M}$. Each value represents the mean \pm $\mathrm{SE}$ of three independent experiments. 


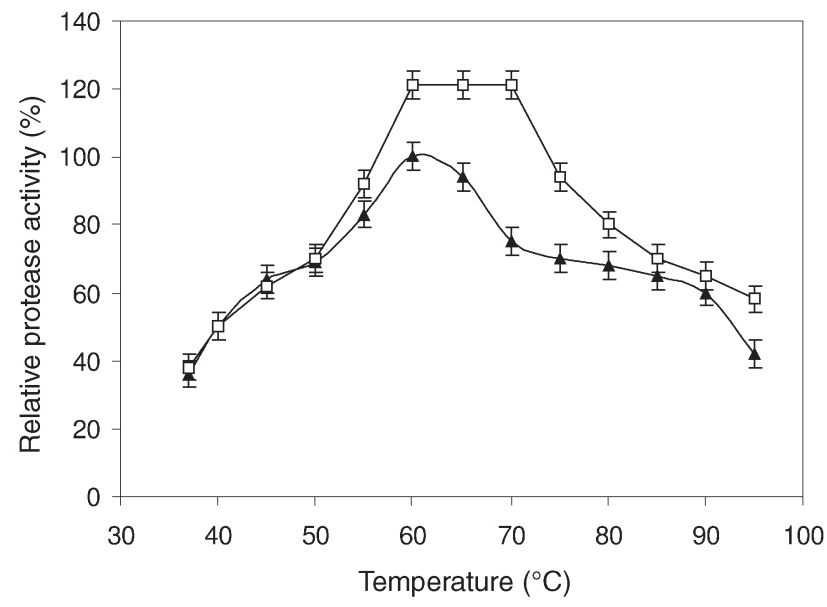

Figure 3. Effect of temperature on purified protease activity. Azocaseinolytic activity was determined in $0.1 \mathrm{M}$ glycine- $\mathrm{NaOH}$ buffer (pH 10.0) with $20 \% \mathrm{NaCl}$ at each temperature after incubation for 15 min with $100 \mathrm{mM} \mathrm{Ca}^{2+}(\square)$ and without $100 \mathrm{mM} \mathrm{Ca}^{2+}(\mathbf{\Delta})$. Each value represents the mean $\pm \mathrm{SE}$ of three independent experiments.

The effects of different concentrations of the osmolytes betaine, glycerol, mannitol and sucrose on the activity of the purified enzyme in the absence of $\mathrm{NaCl}$ were examined. The enzyme was stable and retained $100 \%$ activity in sucrose $(10 \%)$ and betaine $(20 \%)$, indicating that osmotic pressure or reduced water activity is important in maintaining enzymatic activity (Figure 7).

The protease was active on a variety of modified substrates (azocoll and azocasein) or natural proteins (BSA and casein). The protease exhibited the highest activity with azocoll and azocasein (Table 4). Results with synthetic substrates confirmed that trypsin-like activity was absent, as BAPNA, a chromogenic trypsin substrate, was not hydrolyzed. Likewise,

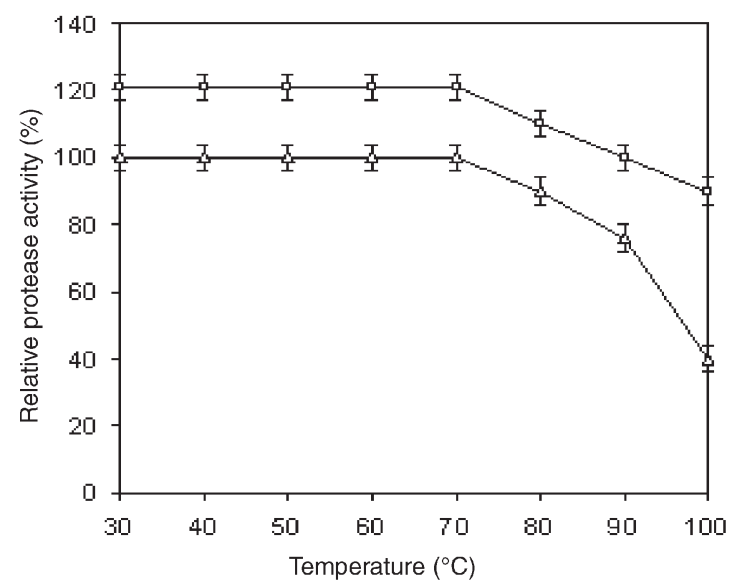

Figure 4. Effect of temperature on the stability of purified protease. The enzyme in glycine- $\mathrm{NaOH}$ buffer $(\mathrm{pH} 10.0)$ with $100 \mathrm{mM} \mathrm{Ca}^{2+}$ $(\square)$ and without $100 \mathrm{mM} \mathrm{Ca}^{2+}(\triangle)$ was preincubated for $1 \mathrm{~h}$ at the specified temperatures. The residual enzymatic activity was measured under the standard conditions. Each value represents the mean $\pm \mathrm{SE}$ of three independent experiments.

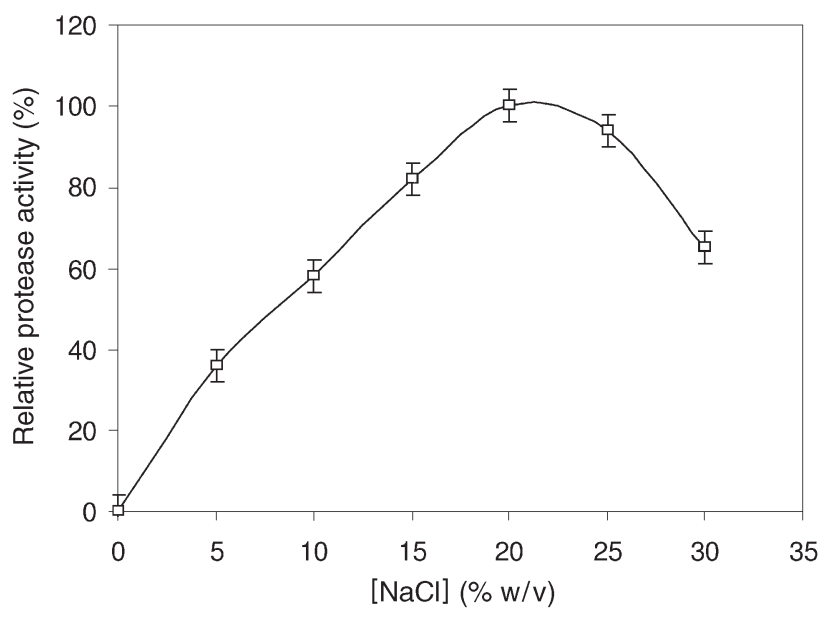

Figure 5. Effect of $\mathrm{NaCl}$ concentration on purified protease activity. Azocaseinolytic activity of protease was determined in $0.1 \mathrm{M}$ glycine- $\mathrm{NaOH}$ buffer $(\mathrm{pH} 10.0)$ at $60^{\circ} \mathrm{C}$ in the presence of the indicated concentrations of $\mathrm{NaCl}$, after incubation for $15 \mathrm{~min}$. Each point represents the mean $\pm \mathrm{SE}$ of three independent experiments.

neither of the ester substrates of trypsin, BAEE and TAME, nor the ester substrates of chymotrypsin, BTEE, tested were hydrolyzed by the enzyme.

\section{Discussion}

In the purification of the highly haloalkaliphilic, thermostable protease produced by $H$. borinquense strain TSS101, precipitation by ethyl alcohol was important in the removal of contaminating proteins and exopolysaccharides. Studdert et al. (1997) similarily purified the halophilic serine protease from Natronococcus occultus.

The molecular mass of $H$. borinquense TSS101 protease estimated by SDS-PAGE was higher than that estimated by gel filtration (Figure 1). The difference between the estimates is likely connected with the resistance of the halophilic protease (an acidic protein) to denaturation in the presence of SDS. The enzyme presumably binds less anionic detergent compared with the marker protein isolated from nonhalophilic organ-

Table 2. Effects of metal ions on purified protease activity.

\begin{tabular}{lcc}
\hline Metal ion & $\begin{array}{l}\text { Concentration } \\
(\mathrm{mM})\end{array}$ & $\begin{array}{l}\text { Relative activity } \\
(\%)\end{array}$ \\
\hline $\mathrm{ZnCl}_{2}$ & 1 & 0 \\
$\mathrm{HgCl}_{2}$ & 1 & 80 \\
$\mathrm{MnCl}_{2}$ & 1 & 12 \\
$\mathrm{MgCl}_{2}$ & 1 & 62 \\
$\mathrm{CaCl}_{2}$ & 100 & 121 \\
$\mathrm{CuCl}_{2}$ & 1 & 0 \\
$\mathrm{BaCl}_{2}$ & 1 & 78 \\
$\mathrm{CoCl}_{2}$ & 1 & 68 \\
$\mathrm{NaSO}_{3}$ & 1 & 96 \\
$\mathrm{KCl}$ & 1 & 100 \\
\hline
\end{tabular}




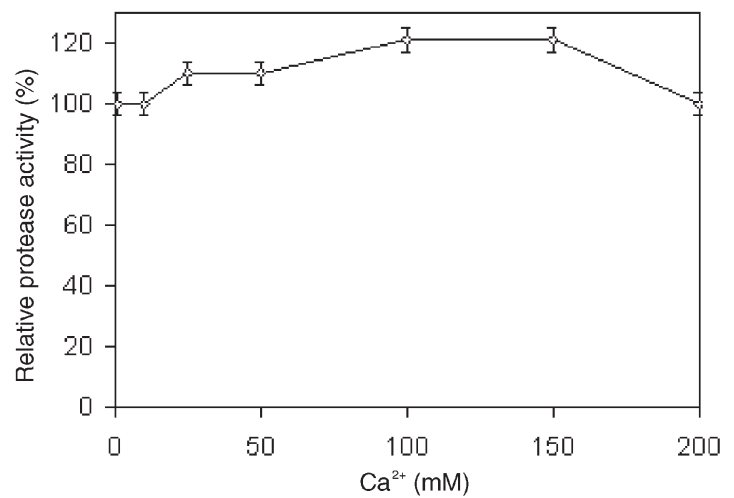

Figure 6. Effect of $\mathrm{Ca}^{2+}$ on purified protease activity. The enzyme was incubated with different concentrations of $\mathrm{Ca}^{2+}$ at $60{ }^{\circ} \mathrm{C}, 20 \% \mathrm{NaCl}$ and $\mathrm{pH} 10.0$, and the relative activity was measured. Each value represents the mean $\pm \mathrm{SE}$ of three independent experiments.

isms. This led to reduced mobility of the SDS-protease complex and to an overestimation of the enzyme's molecular mass. A difference in molecular mass estimated by SDS-PAGE and gel filtration was reported in the case of a serine protease purified from Halobacterium salinarum (Izotova et al. 1983). Different molecular masses for different halophilic proteases have been reported by gel filtration: $130 \mathrm{kDa}$ for Natronococcus occultus halophilic protease (Studdert et al. 2001); $42 \mathrm{kDa}$ for halolysin 172P1 (Kamekura and Seno 1990); $49 \mathrm{kDa}$ for Natronobacterium sp. (Yu 1991); $60 \mathrm{kDa}$ for Halobacterium halobium protease TuA4 (Schmitt et al. 1990); and $45 \mathrm{kDa}$ for Natrialba magadii (Gimenez et al. 2000).

A minimum of $1 \mathrm{M} \mathrm{NaCl}$ is required for enzyme stability. Similar observations have been reported for halolysin 172P1 (Kamekura and Seno 1990), the halophilic protease produced by Natrialba magadii (Gimenez et al. 2000), and the haloalkaliphilic serine protease produced by N. occultus (Studdert et al. 2001), but not for the extracellular protease of Halobacterium halobium which became completely inactivated after 10 days under the same conditions (Izotova et al. 1983). In

Table 3. Effects of chelators, detergents and inhibitors on purified protease activity.

\begin{tabular}{lcc}
\hline Inhibitor & Concentration & $\begin{array}{l}\text { Relative activity } \\
(\%)\end{array}$ \\
\hline PMSF & $1 \mathrm{mM}$ & 3 \\
EDTA & $1 \mathrm{mM}$ & 65 \\
EDTA & $10 \mathrm{mM}$ & 38 \\
SDS & $0.1 \%$ & 53 \\
Triton x-100 & $1 \%$ & 80 \\
CTAB & $0.1 \%$ & 159 \\
2-Mercaptoethanol & $1 \mathrm{mM}$ & 81 \\
Urea & $8 \mathrm{M}$ & 44 \\
1,10-Phenanthroline & $10 \mathrm{mM}$ & 76 \\
DTT & $10 \mathrm{mM}$ & 81 \\
PCMB & $1 \mathrm{mM}$ & 80 \\
Pepstatin & $1 \mathrm{mM}$ & 82 \\
\hline
\end{tabular}

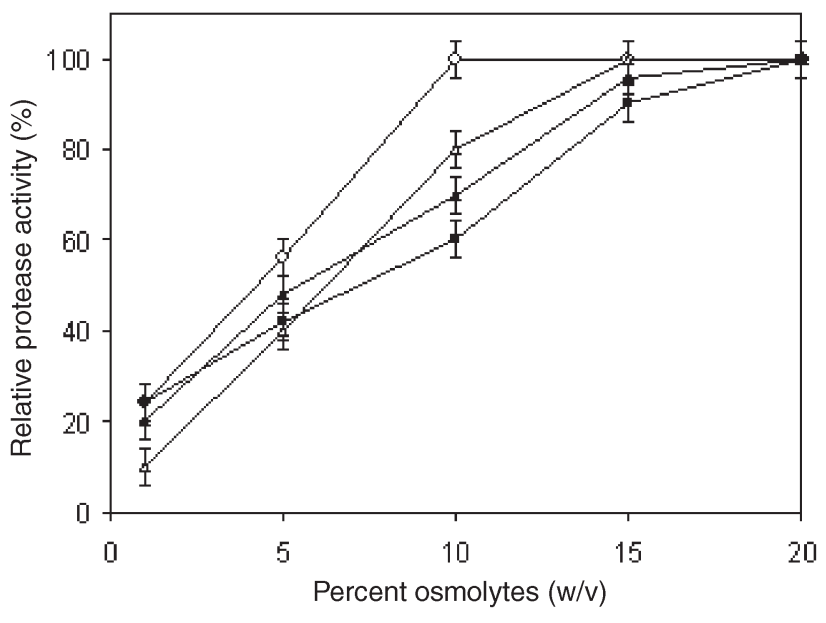

Figure 7. Effects of osmolytes on the purified protease activity in the absence of $\mathrm{NaCl}$. The enzyme was incubated in the various concentrations of osmolytes: sucrose $(\diamond)$; mannitol $(\boldsymbol{\Delta})$; glycerol $(\triangle)$; and betaine ( $\mathbf{\square})$ without $\mathrm{NaCl}$ in standard assay conditions. Each value represents the mean $\pm \mathrm{SE}$ of three independent experiments.

the presence of $20 \%(\mathrm{w} / \mathrm{v}) \mathrm{NaCl}$, the enzyme was stable from 30 to $70{ }^{\circ} \mathrm{C}$ without loss of activity and retained $80 \%$ activity at $90{ }^{\circ} \mathrm{C}$ for $1 \mathrm{~h}$. Thermostability studies of proteases reported in the literature show stable enzymes with a half-life of $1 \mathrm{~h}$ at $50{ }^{\circ} \mathrm{C}$ (Bhosale et al. 1995), $25 \mathrm{~min}$ at $60{ }^{\circ} \mathrm{C}$ or, for the serine protease, subtilisin Carlsberg, with a half-life of $2.5 \mathrm{~min}$ at $60{ }^{\circ} \mathrm{C}$ (Durhan et al. 1987). By comparison, our results show a much greater thermal stability at $70{ }^{\circ} \mathrm{C}$. In the conditions of an industrial laundry, where alkaline proteases are commonly used for $10 \mathrm{~min}$ at $60{ }^{\circ} \mathrm{C}$, the high thermostability of the protease from $H$. borinquense might be advantageous.

The thermostability of the enzyme increased by $10^{\circ} \mathrm{C}$ in the presence of $\mathrm{Ca}^{2+}$ (Figure 4). Consistent with this finding, $10 \mathrm{mM}$ EDTA, a chelating agent for calcium ions, caused a $68 \%$ reduction in enzyme activity (Table 3 ). Activation and stabilization by $\mathrm{Ca}^{2+}$ has also been observed in bacterial serine proteases (Kelly and Fogarty 1976, Strongin et al. 1978, Ward 1983) and an extracellular protease, caldolysin, produced by the thermophilic bacterium, Thermus aquaticus (Cowan and Daniel 1982). The protease from $H$. borinquense is a serine protease as shown by its complete inactivation by PMSF, a

Table 4. Substrate specificity of purified protease. Specific activity values are means of triplicate determinations \pm SD.

\begin{tabular}{ll}
\hline Substrate & Specific activity $\left(\mathrm{U} \mathrm{mg}^{-1}\right)$ \\
\hline Casein $0.1 \%$ (Hammerstein) & $262 \pm 5.291$ \\
BSA $0.1 \%$ & $180 \pm 5.033$ \\
Azocasein $0.4 \%$ & $350 \pm 3.464$ \\
Azocoll $0.1 \%$ & $1248 \pm 7.571$ \\
BAPNA & 0 \\
BAEE & 0 \\
TAME & 0 \\
BTEE & 0 \\
\hline
\end{tabular}


common inhibitor of these enzymes (Morihara 1974, Ward 1983). This protease is more stable in anionic detergents than in cationic detergents, with activity enhanced $59 \%$ by CTAB.

Osmolytes stabilized the protease in the absence of added $\mathrm{NaCl}$ (Figure 7). Halophiles respond to increases in osmotic pressure in different ways. The accumulation by halophilic bacteria of compatible organic solutes, such as glycine, betaine, sugars, polyols, amino acids and ectoines, helps them to maintain an internal environment isotonic with the growth medium (Galinski 1993, Danson and Hough 1997, Da Costa et al. 1998). These substances also help to protect cells and enzymes against stress due to high temperature, desiccation and freezing (Galinski 1993, Danson and Hough 1997, Mevarech et al. 2000). However, to date, these compatible organic solutes are known to serve as significant osmolytes only among halophilic bacteria. In general, Haloarchaea use $\mathrm{K}^{+}$as the internal inorganic compatible solute.

The enzyme was unaffected by a specific trypsin inhibitor. Moreover, it was unable to hydrolyze trypsin substrates (Table 4), the characteristics of the enzyme are thus not those of a trypsin-type protease. Similarly, proteases from B. stearothermophilus F1 (Rahman et al. 1994) and B. thermoruber (Manachini et al. 1988) also fail to show trypsin-like activity. The $\mathrm{pH}$ and temperature stability in presence of such high salt concentration of the investigated protease from $H$. borinquense strain TSS101 suggest that it may have potential application in the formulation of detergents and in the fermentation of seafood.

\section{Acknowledgments}

Dr. K. Sreeramulu thanks the Department of Science and Technology (DST), Government of India, for financial assistance through a research project SP/SO/D-56/99 dated December 11, 2001. Financial assistance to Malashetty Vidyasagar was funded by the UGC/CSIRJRF, Government of India, Reference No. F1/17-98/98 (SA-I).

\section{References}

Adams, M.W.W. and R.M. Kelly. 1995. Enzymes from microorganisms in extreme environments. Chem. Eng. News 73:32-42.

Bhosale, S.H., M.B. Rao, V.V. Deshpande and M.C. Srinivasan. 1995. Thermostability of high activity alkaline protease from Conidiobolus coronatus (NCL 86.8.20). Enzyme Microb. Technol. 17: 136-139.

Brock, F.M., C.W. Frosberg and J.G. Buchanan-Smith. 1982. Proteolytic activity of rumen microorganisms and effect of proteinase inhibitors. Appl. Environ. Microbiol. 44:561-569.

Cowan, D.A. and R.M. Daniel. 1982. Purification and some properties of an extracellular protease (caldolysin) from an extreme thermophile. Biochim. Biophys. Acta 705:293-305.

Da Costa, M.S., H. Santos and E.A. Galinski. 1998. An overview of the role and diversity of compatible solutes. Adv. Biochem. Eng. Biotechnol. 61:117-153.

Danson, M.J. and D.W. Hough. 1997. The structural basis of protein halophilicity. Comp. Biochem. Physiol. 117:307-312.

Durhan, D.R., D.B. Stewart and E.J. Stellwag. 1987. Novel alkaline protease and heat stable serine protease from alkaliphilic Bacillus sp. strain GX6638. J. Bacteriol. 169:2762-2768.
Galinski, E.A. 1993. Compatible solute of halophilic eubacteria: molecular principles, water solute interaction, stress protection. Experientia 49:487-496.

Gimenez, M.I., C.A. Studdert, J.J. Sanchez and R.E. De Castro. 2000. Extracellular protease of Natrialba magadii; purification and biochemical characterization. Extremophiles 4:181-188.

Gomes, J. and W. Steiner. 2004. The biocatalytic potential of extremophiles and extremozymes. Food Technol. Biotechnol. 42: 223-235.

Gupta, R.K., R.K. Saxena and K. Seema. 1999. Bleach stable alkaline protease from Bacillus sp. Biotechnol. Lett. 21:135-138.

Hough, W.D. and M.J. Danson. 1999. Extremozymes. Curr. Opinion Chem. Biol. 3:39-46.

Izotova, L.S., A.Y. Strongin, L.W. Chekulaeva, V.E. Sterkin, V.I. Ostoslavskaya, E.A. Lyublinskaya, E.A. Timokhina and V.M. Stepanov. 1983. Purification and properties of serine protease from Halobacterium halobium. J. Bacteriol. 155:826-830.

Kelly, C.T. and W.M. Fogarty. 1976. Microbial alkaline enzymes. Process. Biochem. 11:3-9.

Kushner, D. and M. Kamekura. 1988. Physiology of halophilic eubacteria. In Halophilic Bacteria. Ed. F. Rodriguez-Valera. CRC Press, Boca Raton, FL, pp 109-138.

Kamekura, M. and Y. Seno. 1990. A halophilic extracellular protease from a halophilic archaebacterium strain 172p1. Biochem. Cell Biol. 68:352-359.

Laemmli, U.K. 1970. Cleavage of structural proteins during assembly of the head of bacteriophage T4. Nature 277:680-685.

Lowry, O.H., N.J. Rosebrough, A.L. Farr and J.R. Randall. 1951. Protein measurement with the Folin phenol reagent. J. Biol. Chem. 193:265-275.

Madern, D., C. Ebel and G. Zaccai. 2000. Halophilic adaptation of enzymes. Extremophiles 4:91-98.

Manachini, P.L., M.G. Fortina and C. Parini. 1988. Thermostable alkaline protease produced by Bacillus thermoruber-a new species of Bacillus. Appl. Microbiol. Biotechnol. 28:409-413.

Margesin, R. and F. Schiner. 2001. Potential of halotolerant and halophilic microorganisms for biotechnology. Extremophiles 5: 73-83.

Mevarech, M., F. Frolow and L.M. Gloss. 2000. Halophilic enzymes: proteins with a grain of salt. Biophys. Chem. 86:155-164.

Montalvo-Rodriguez, R., R.H. Vreeland, A. Oren, M. Kessel, C. Betancourt and J. Lopez-Garriga. 1998. Halogeometricum borinquense gen. Nov., sp. nov., a novel halophilic archaeon from Puerto Rico. Int. J. Syst. Bacteriol. 48:1305-1312.

Morihara, K. 1974. Comparative specificity of microbial proteinases. Adv. Enzymol. 41:179-243.

Norberg, P. and B.V. Hofstein. 1969. Proteolytic enzymes from extremely halophilic bacteria. J. Gen. Microbiol. 55:251-256.

Rahman, R.N.Z., C.N. Razak, K. Ampon, M. Basri, W. Zin Wan Yunus and B. Salleh. 1994. Purification and characterization of a heat stable alkaline protease from Bacillus stearothermophilus F1. Appl. Microbiol. Biotechnol. 40:822-827.

Schmitt, W., U. Rdest and W. Goebel. 1990. Efficient high performance liquid chromatographic system for the purification of a halobacterial serine protease. J. Chromatogr. 521:211-220.

Schiraldi, C., M. Giuliano and M. De Rosa. 2002. Perspectives on biotechnological applications of archaea. Archaea 1:75-86.

Stepanov, V.M., G.N. Rudenskaya, L.P. Revina, Y.B. Gryaznova, E.N. Lysogorskaya, I.Y. Filippova and I.I. Ivanova. 1992. A serine proteinase of archaebacterium, Halobacterium mediterranei, a homologue of an eubacterial subtilisin. Biochem. J. 285:281-286. 
Strongin, A.Y.A., L.S. Tzotova, Z.T. Abramov, D.I. Gorodetsky, L.M. Ermakova, L.A. Baratova, L.P. Belyanova and V.M. Stepanov. 1978. Intracellular serine protease of Bacillus subtilis: sequence homology with extracellular subtilisin. J. Bacteriol. 133: 1401-1411.

Studdert, C.A., R.E De Castro, M.K. Herrera Seitz and J.J. Sanchez. 1997. Detection and preliminary characterization of extracellular proteolytic activities of the haloalkaliphilic archaeon Natronococcus occultus. Arch. Microbiol. 168:532-535.

Studdert, C.A., M.K. Herrera Seitz, M.I. Plasencia Gil, J.J. Sanchez and R.E. De Castro. 2001. Purification, biochemical characterization of the haloalkaliphilic archeon Natronococcus occultus extracellular serine protease. J. Gen. Microbiol. 41:375-383.
Thongthai, C. and P. Sontinanalert. 1991. Halophiles in Thai fish sauce: general and applied aspects of halophilic bacteria. Vol. 20. Ed. F.R. Rodriguez-Valera. Plenum Press, New York, pp 381-389. van den Berg, B. 2003. Extremophiles as a source for novel enzymes. Curr. Opinion Microbiol. 6:213-218.

Ward, O.P. 1983. Proteinases. In Microbial Enzymes and Biotechnology. Ed. W.M. Fogarty. Applied Science Publication, New York, pp 251-317.

Yu, X.T. 1991. Protease of haloalkaliphiles. In Superbugs. Eds. K. Horikoshi and W.D. Grant. Springer-Verlag, New York, pp $76-83$. 

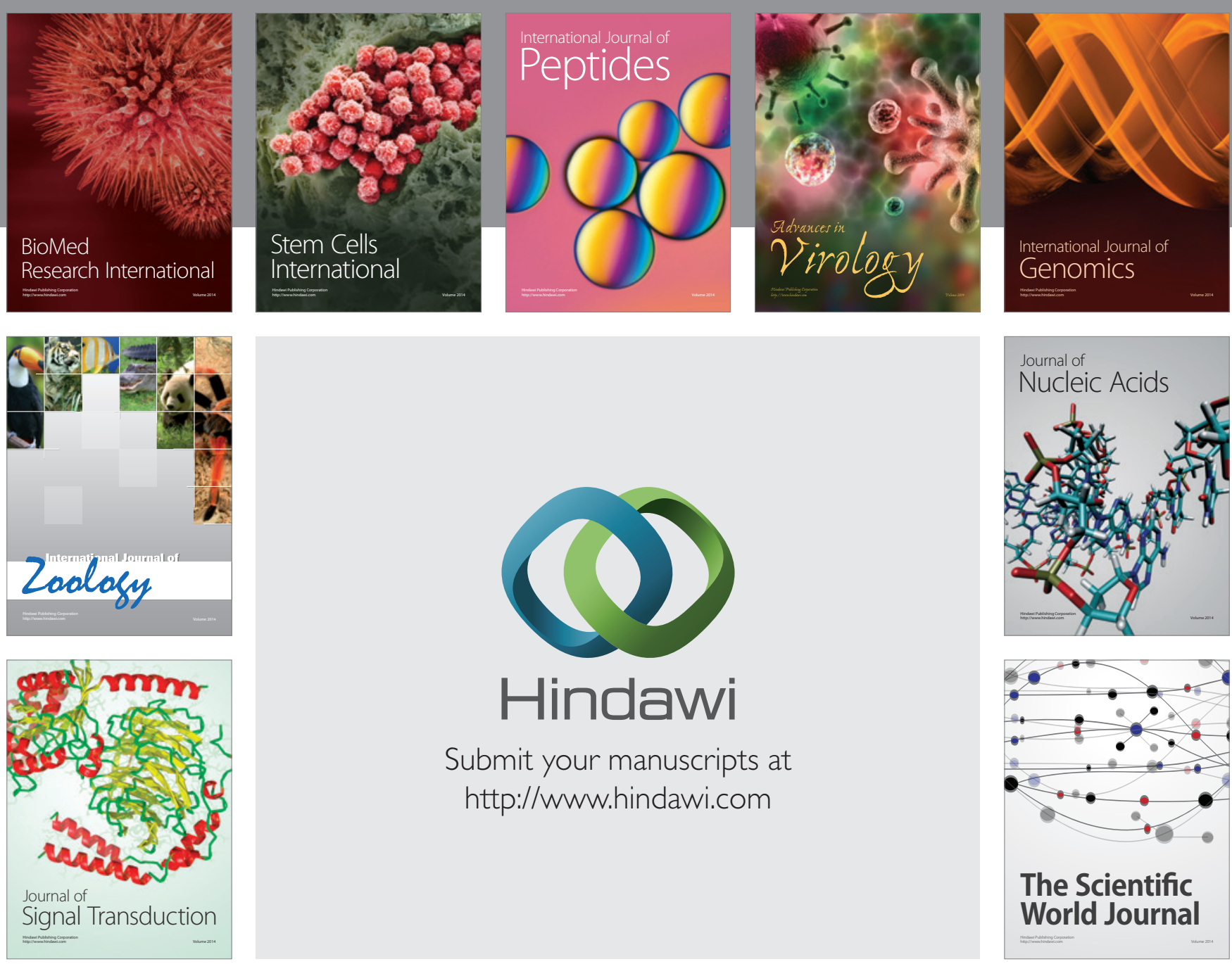

Submit your manuscripts at

http://www.hindawi.com
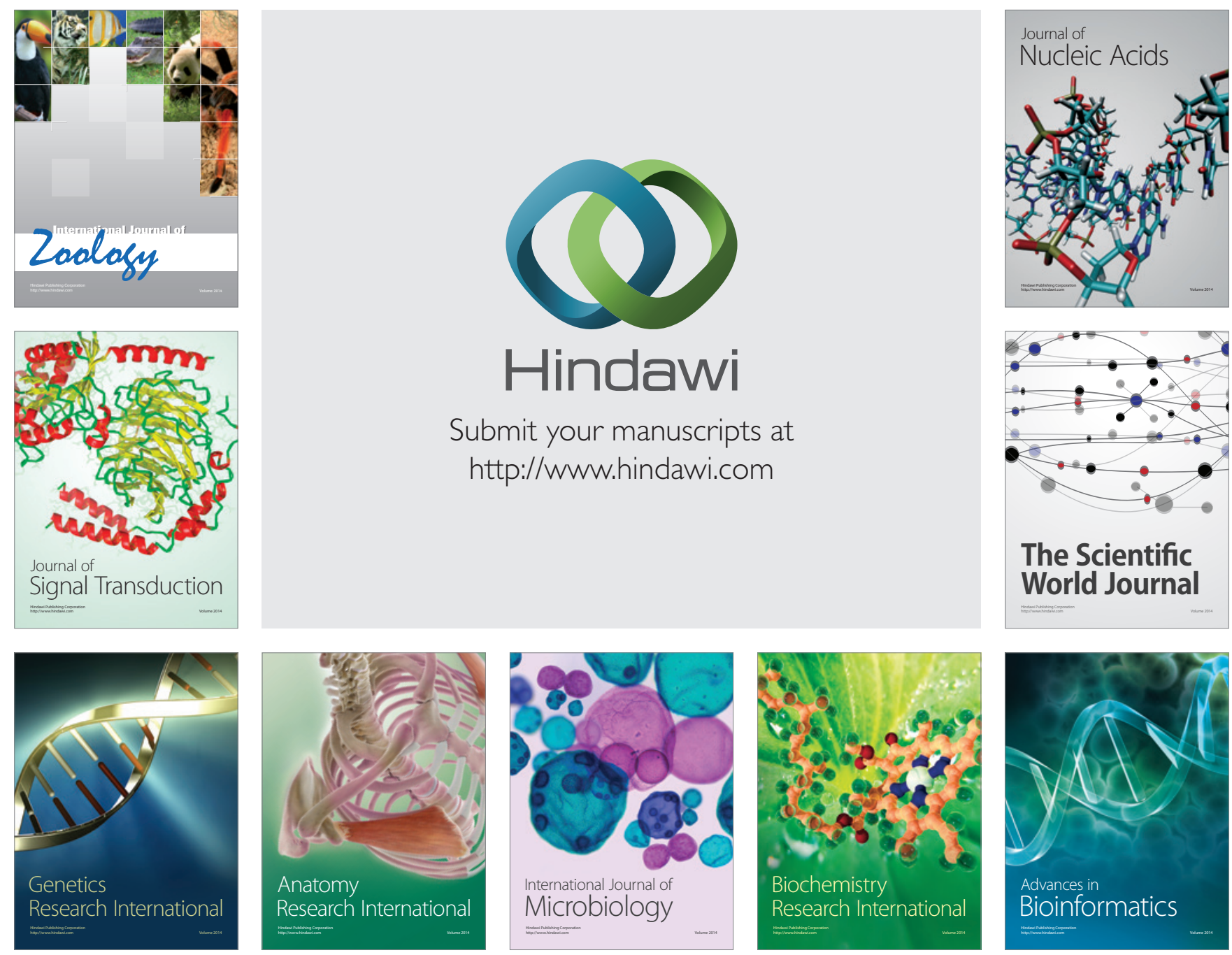

The Scientific World Journal
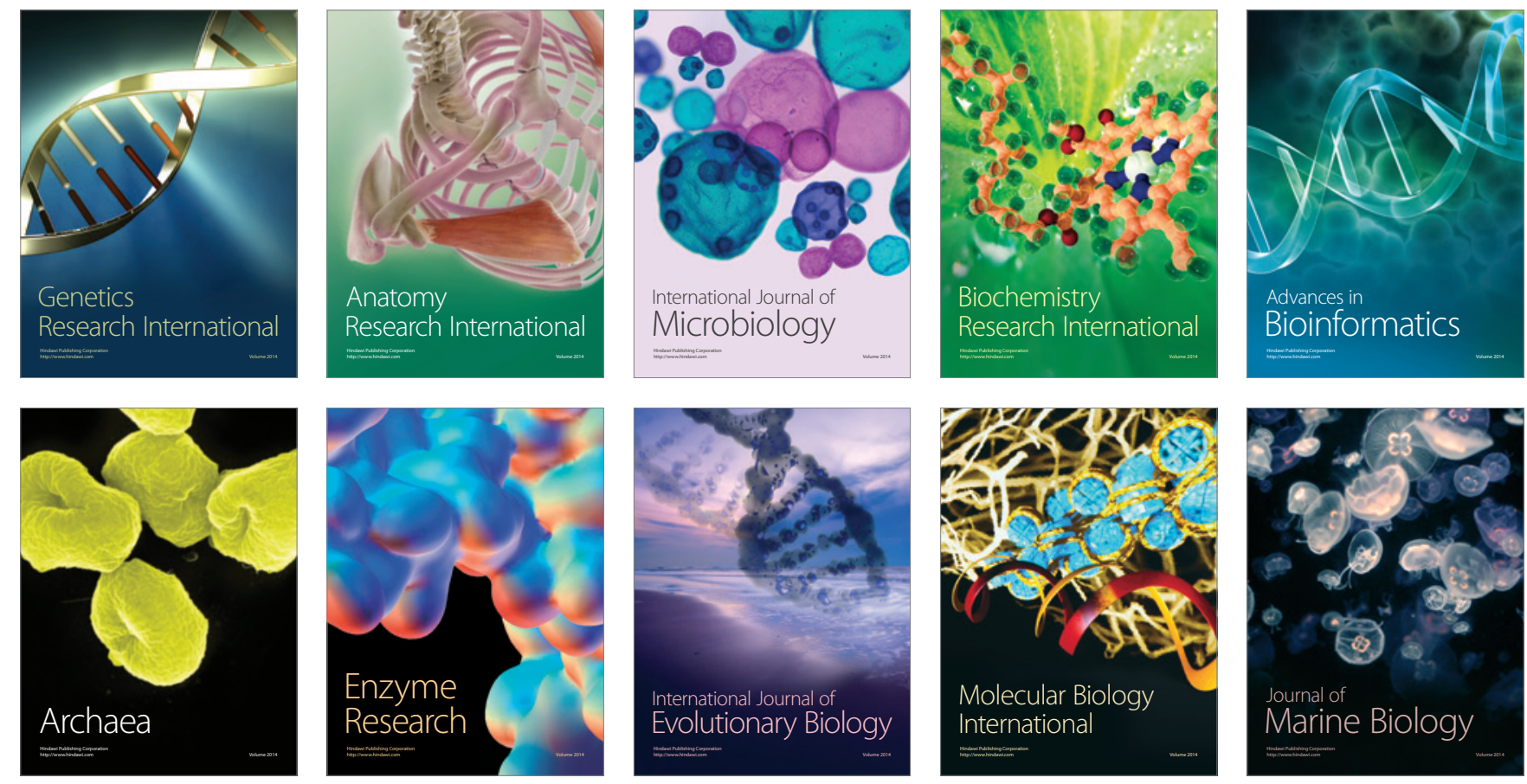